\title{
Winner of the SLS Annual Conference Best Paper Prize 2013
}

\section{Bogeymen, lunatics and fanatics: collective actions and the private enforcement of European competition law}

\author{
Bruce Wardhaugh* \\ Queen's University Belfast
}

The European desire to ensure that bearers of EU rights are adequately compensated for any infringement of these rights, particularly in cases where the harm is widely diffused, and perhaps not even noticed by those affected by it, collides with another desire: to avoid the perceived excesses of an American-style system of class actions. The excesses of these American class actions are in European discourse presented as a sort of bogeyman, which is a source of irrational fear, often presented by parental or other authority figures. But when looked at critically, the bogeyman disappears. In this paper, I examine the European (and UK) proposals for collective action. I compare them to the American regime. The flaws and purported excesses of the American regime, I argue, are exaggerated. A close, objective examination of the American regime shows this. I conclude that it is not the mythical bogeyman of a US class action that is the barrier to effective collective redress; rather, the barriers to effective, wide-ranging group actions lie within European legal culture and traditions, particularly those mandating individual control over litigation.

Bruce Wardhaugh, Lecturer, School of Law, Queen's University Belfast, 27-30 University Square, Belfast BT7 1NN, UK. Email: b.wardhaugh@qub.ac.uk

. . only a lunatic or a fanatic sues for $\$ 30 .^{1}$

- Judge Richard Posner

\section{INTRODUCTION}

Small and diffuse harms are an unfortunate part of contemporary life. Some of these harms may be the fault of others and thus may be compensable. However, if the hassle faced by an individual for obtaining redress exceeds the value of the payment, the harmed individual is likely to walk away from making a claim. If the harm has affected a significant number of people who in turn abandon their claims, the party that perpetuated this harm benefits. They need not make redress. Some form of

* This paper was presented at the EU and Competition Law Section of the Annual Meeting of the Society of Legal Scholars at Edinburgh, in September 2013. I wish to thank those attending the session and the anonymous reviewers, whose comments and suggestions have improved this paper. All websites were verified on 13 October 2013. The usual disclaimers apply.

1. Carnegie v Household International Inc 376 F 3d 656 at 661 (CA7 2004). 


\section{Legal Studies, Vol. 34 No. 1}

collective redress - aggregating the small claims into one larger claim that is worth pursuing, then distributing the award to those affected - appears to be an appropriate solution to achieving compensation for mass damages, particularly where the individual amounts are relatively small.

Competition injuries are paradigmatic of the sorts of harms that are amenable to collective redress. An indirect purchaser might not be aware of the scope of her injury, or even the fact that she has been injured by anti-competitive conduct. The purchaser of breakfast cereal is unlikely to be aware that she is paying 'too much' as a result of the cartelised price of the pressboard box of the cereal package. Even for a direct purchaser, the amounts at stake may be insignificant, or outweighed by the costs associated in recouping the overcharge. Collective action could assist in enabling affected consumers to recover what they have overpaid, disgorging an illicit profit from the price-fixer, and potentially adding further deterrence to such conduct.

But the European desire to ensure that bearers of rights are compensated for infringements of these rights collides with another desire: to avoid the perceived excesses of an American-style system of class actions. The force of this collision is sufficiently powerful that, one scholar notes, 'The aversion towards American class actions in Europe is so great that it has become politically incorrect to use this term. Instead, policy makers have proposed to rely on "collective actions" and "representative actions" brought by consumer associations.' 2 By using alternative terms to rebrand the American product, and developing substitutes for it, European legislators hope to fashion an appropriate procedural means to vindicate individual rights and avoiding the apparent difficulties presented by the American system. The perceived problem with the American product is that it is viewed as promoting unmeritorious and inflated claims advanced by self-interested counsel, which have the effect of extorting settlements from defendants. This perception of that regime has coloured European discussion on developing adequate means of redress for these sorts of harms.

This paper examines recent EU and UK legislative and governmental views to collective action in competition matters. I argue that collective actions are essential means of vindicating individual rights in an effective competition regime. Although a significant amount of work (both academic and governmental/policy) in recent years has been directed towards the use of collective redress regimes in competition law, the need for collective redress is not located solely in the context of this area of law. Other sorts of consumer harms (eg the mis-selling of financial products or useless warrantees $)^{3}$ and some tort harms ${ }^{4}$ are also amenable to collective actions as a form of redress. As such, the implications of this paper's argument extend beyond the borders of competition law. However, given the wealth of material discussing the possible utility of collective actions in competition matters, this will be the focus of the paper.

The focus of my argument is that the fear of American-style class action is misplaced. Indeed, in European discourse the US class action acts as a sort of bogeyman, a source of irrational fear, often presented by parental or other authority

2. R Van Den Bergh 'Private enforcement of European competition law and the persisting collective action problem' (2013) 20 Maastricht J Eur \& Comp L 12 at 13.

3. See eg the Green Paper on Consumer Collective Redress (presented by the Commission), Brussels, 27 November 2008, COM(2008) 794 final (available at http://ec.europa.eu/consumers/ redress_cons/greenpaper_en.pdf) for a discussion of the need of collective action in consumer matters.

4. See below, text accompanying nn 85-89, for a discussion of the Dutch settlement regime designed to handle the effective resolution of mass torts. 
figures to facilitate the obedience of children. ${ }^{5}$ Bogeyman stories, if told often enough, become both believed and a real source of fear. Parents then need to shine a light in the child's closet to show them that the bogeyman doesn't exist. The closet examined, the child can then go to sleep. Class action stories are bogeyman stories, and the purpose of this paper is to serve as the metaphorical parental flashlight. But notwithstanding this, I suggest the real barriers to implementing an effective collective redress regimes lie within European legal traditions, and particularly that tradition which mandates individual control over litigation. To the extent that this tradition is at least in part cultural, it may well be that cultural barriers form part of the problem.

At the outset, I wish to make two methodological points. First, this paper is not an anthropological study of European legal traditions - such analysis is well beyond its scope. Rather, it takes for granted the premise that cultural attitudes shape legal institutions and discussions about these institutions. Following on this premise, the paper also accepts that a society's institutions can themselves be examined to determine what this may reflect regarding the beliefs and assumptions of those designing and using them. Social attitudes regarding collective action may well be reflective of such beliefs. ${ }^{6}$ Secondly, I also note that the approach of this paper is within the 'law and economics' tradition, as is the case with much writing in competition law. This approach aids in providing an element of analytical clarity to the discussion; however, in the present context few - if any - normative consequences flow from this approach.

This paper is organised as follows: the following section discusses the need for collective actions in the context of rational apathy, which is the recognition that pursuit of any goal involves a cost, and often the expected costs of pursuing a claim outweigh the expected benefit of obtaining a result. This is the problem that collective actions solve. The second section considers the American system of class actions, examining it in light of criticisms commonly voiced in Europe and showing that these criticisms are based on misunderstandings of the nature of the American system. The third section considers the European context of private competition actions, examining both the rights to such damages under European law and the limits found with in national law and national constitutional regimes to group recovery. The fourth section considers the responses to the need for collective redress by the European Parliament and Commission and the UK government. The paper ends with some concluding remarks regarding the utility of opt-in actions. The conclusion is sceptical: as effective as such actions may be, traditional attitudes regarding individual control over

5. There is an extensive literature regarding the place of bogeymen in folklore and our cultural tradition. See eg J Widdowson 'The bogeyman: some preliminary observations on frightening figures' (1971) Folklore 99 at 99: 'When we speak of bogeys or bogeymen we may perhaps think primarily of childhood days when they may have had a specific meaning for each of us. On the other hand as adults we may simply use these words as general cover-terms for anything which inspires fear.' And also M Warner No Go the Bogeyman: Scaring, Lulling, and Making Mock (London: Chatto and Windus, 1998), in particular pp 30-31 for the role of such stories in facilitating the obedience of children.

6. An interesting illustration of this point may be found in the current US Federal Rules regarding class actions. The present rules were a result of 1966 amendments to the Federal Rules of Civil Procedure, and resulted in a strengthening of the ability to pursue collective actions. It was not really a coincidence that this sort of facilitation of group action occurred during the same era as other legislative efforts to encourage collective action, such as the Civil Rights Act of 1964 and the Voting Rights Act of 1965. See eg AR Miller 'Of Frankenstein monsters and shining knights: myth, reality, and the "class action problem" ' (1978) 92 Harv L Rev 664 at $670-671$. 
litigation and consent to having one's legal rights altered may be the most profound obstacle to the introduction of opt-in actions in Europe.

\section{RATIONAL APATHY AND THE NEED FOR COLLECTIVE ACTIONS}

A rational agent will act only if the expected benefit of the action exceeds the action's expected costs. This insight underlies the design and analysis of some ${ }^{7}$ legal institutions. In the context of civil procedure, the implication of this insight is that a potential litigant will commence a lawsuit only if the expected gain from that action exceeds the cost of the suit. Indeed, in this context, Judge Posner's remarks used as the epigraph and the phrase 'rational apathy' ${ }^{8}$ well capture the response of a right-minded individual faced with mounting a small legal claim.

It is precisely this sort of rational apathy to ' $\$ 30$ claims' that collective action can solve. By bundling a number of small-value matters into one suit and consolidating the costs of prosecuting it, the expected value of the litigation can exceed its costs. This consolidation makes such a suit worth pursuing, and thus serves as a vehicle for the redress of small-value harms.

The American In re NASDAQ Market-Makers Antitrust Litigation ${ }^{9}$ case illustrates the advantages of such consolidation. NASDAQ involved a class of over one million investors (individual and institutional) who claimed losses as a result of alleged price-fixing in the quotes and price spreads on the exchange. ${ }^{10}$ The suit was settled for slightly over $\$ 1$ billion, with plaintiffs' attorney's fees of $14 \% .^{11}$ While the mean claim was around $\$ 1000$ - or $3300 \%$ of what only a 'lunatic or a fanatic' would sue for - it would be highly unlikely that an institutional or individual investor would instruct and fund counsel to recover this sum, in a case that was complicated to prove. ${ }^{12}$ Even if such cases were pursued in a forum, such as a small claims court, that discourages the use of legal professionals, judges in such a forum might not have the expertise to adequately resolve such matters. Further, even if such claims were 'follow on' claims after another court's or authority's finding of an infringement, the issues of awareness of the finding of infringement by the affected parties and the hassle of pursuing the small claims litigation would still hinder this means of recourse. ${ }^{13}$

The British Replica Football Kit matter is a contrast. ${ }^{14}$ In that claim, the Consumers' Association (known as 'Which?') sought compensation for those affected by the

7. See eg GS Becker 'Crime and punishment: an economic approach' (1968) 76 J Pol Econ 169; RA Posner Economic Analysis of the Law (Boston: Little, Brown, 1st edn, 1972) p 56 compare, however, his remarks in the eight edition (New York: Aspen, 8th edn, 2011) pp 149-158; and Judge Hand's negligence formula in United States et al v Carroll Towing Co Inc, et al $159 \mathrm{~F} 2 \mathrm{~d} 169$ at 173 (CA2 1947).

8. See eg Van den Bergh, above n 2, at 20; and JG Delatare 'Beyond the White Paper: rethinking the Commission's proposal on private antitrust litigation' (2011) 8 Comp L Rev 29 at 45 .

9. 187 FRD 465 (SDNY 1998).

10. Ibid, at 470-471.

11. Ibid, at 470 .

12. On the difficulty of the case, see ibid, at 474-476.

13. I am indebted to an anonymous reviewer who pointed this out.

14. Competition Appeal Tribunal Case No 1078/7/9/07 (12 March 2007); see Delatre, above n 8 , at 47 for other examples. 
price-fixing of replica football jerseys. Less than 150 consumers obtained redress in the amount of $£ 20 .{ }^{15}$ This amount approximates Posner's 'lunatic and fanatic' threshold.

The difference in the effectiveness of the two actions is only explained by the means by which victims became class members. Replica Football Kit was governed by an opt-in rule; that is, in order to benefit from the proposed settlement, prospective class members had to actively take steps to join the class. In $N A S D A Q$, the class was certified under the opt-out US regime, meaning that all those affected were class members, unless they took active steps to withdraw from the class. As will be discussed below, even opting into a class has its costs, which can give rise to rational apathy.

While an opt-out class action regime may have obvious intuitive appeal, such a regime is not without its critics. The American opt-out system, perhaps because of its propensity to allow for the production of newspaper headlines announcing a significant award for an apparently trivial harm, is often presented as the 'system not to be emulated' due to these supposed excesses. However, when the claimed excesses are examined with some diligence, it will readily be seen that these notorious features are for the most part illusory.

\section{CLASS ACTIONS: THE AMERICAN BOGEYMAN}

Those critical of a class action regime frequently cite the perceived excesses of the American regime, of which the following three claims are typical: (1) the class action regime is fuelled by runaway juries that grant disproportionately large awards of damages; (2) class actions are run by self-serving counsel, who seek to enrich themselves at the expense of their clients; and (3) generous rules regarding class composition make the pursuit of such actions an easy task, enabling them to be used to extract undeserved settlements from possibly innocent defendants. While there may be a small element of truth to these points, their force rests on fundamental misunderstandings about the American class action regime. In the remainder of this section, I address each of these concerns in turn.

\section{(a) Disproportionality in awards}

The first point, the issue of runaway juries and disproportionate awards, is very much a straw man. Engle v RJ Reynolds Tobacco ${ }^{16}$ is often cited as support for the claim regarding runaway juries. This is the infamous Florida matter in which damages of $\$ 145$ billion were awarded against the tobacco industry. That sum represented over 17 times 'the combined net worth of all major cigarette manufacturers' ${ }^{17}$ The problem in using Engle, or other blockbuster class action cases, is that the amount of damages is a result of an award of punitive damages, rather than compensatory damages to the

15. See Which? 'JJB Sports: a case study in collective action' (July 2011), available at http://www.which.co.uk/documents/pdf/collective-redress-case-study-which-briefing-258401 .pdf

16. 2000 WL 33534572 (Fla Cir Ct, 6 November 2000) (NO. 94-08273 CA-22).

17. M Cenini, B Luppi and F Parisi 'Incentive effects of class actions and punitive damages under alternative procedural regimes' (2011) 32 Eur J L \& Econ 229 at 235. 
class. In Engle, such punitive damages were $\$ 144.87$ billion, in comparison to the $\$ 127$ million awarded in compensation. The disproportionate amount of punitive damages was one of the several reasons why this element of the jury's award was vacated. ${ }^{18}$ In the absence of public enforcement, there may be good reasons for punitive damages. However, in the presence of public enforcement, arguments for punitive damages lose their strength. ${ }^{19}$ Indeed, to the extent that such punitive awards are meted out by juries, appeal to the excesses of these awards is somewhat of a red herring in the European context.

Disproportionality can occur where there is a statutory quantification of damages. The Federal Fair and Accurate Credit Transactions Act of $2003^{20}$ requires credit card numbers to be truncated on printed receipts ${ }^{21}$ and provided for statutory damages of between $\$ 100$ and $\$ 1000$ for each failure. ${ }^{22}$ Mama Mia, a restaurant, failed to truncate numbers, resulting in a class action with potentially 46,000 members. ${ }^{23}$ In denying class certification, the District court held:

Here, Defendant is a local business with $\$ 40,000$ in net assets. Yet, if Plaintiff prevails as a certified class representative, he would seek to impose a statutory damages award of between $\$ 4.6$ million and $\$ 46$ million, while also conceding that neither he, or $[s i c]$ any other putative class member, suffered actual economic injury. Thus, if Plaintiff's strategy is successful, Mama Mia would face almost certain insolvency, despite the fact that its conduct caused no actual damages. ${ }^{24}$

Again, the problem is not with the class nature of the action, but with the amassed effect of non-compensatory damages.

\section{(b) Agency issues in class representation}

The second point, lawyers enriching themselves at expense of the class members, is an oft-voiced criticism of the class action regime. Macey and Miller note the problem thus:

... the single most salient characteristic of class and derivative litigation is the existence of 'entrepreneurial' plaintiffs' attorneys. Because these attorneys are not subject to monitoring by their putative clients, they operate largely according to their own self-interest, subject only to whatever constraints might be imposed by bar discipline, judicial oversight, and their own sense of ethics and fiduciary responsibilities. ${ }^{25}$

The agency problems in class action are evident. The class consists of a large number of individuals, each of whom has a small value claim. The small value of the

18. 945 So 2 d 1246 at $1262-1265$ (Fla SC 2006).

19. From a Beckarian perspective, above $n$, activity will be prevented if the expected costs of participating in it exceed the expected gain. Where the probability of detection is less than 1 , punitive damages are needed to raise the costs of the activity to exceed their expected gain, unless public enforcement adds this increase.

20. Codified at 15 USC $\S 1681$ et seq.

21. 15 USC $\S 1681 \mathrm{c}(\mathrm{g})(1)$.

22. 15 USC $\S 1681 \mathrm{n}(\mathrm{a})(1)(\mathrm{A})$.

23. Leysoto v Mama Mia I, Inc 255 FRD 693 (SD Fla 2009).

24. Ibid, at 698 .

25. JR Macey and GP Miller 'The plaintiffs' attorney's role in class action and derivative litigation: economic analysis and recommendations for reform' (1991) 58 U Chi L Rev 1 at 7-8. 
member's stake in the outcome of the litigation provides little incentive for that member to monitor how his agent (the class' attorney) pursues the action. A selfinterested attorney will act as any self-interested agent will: preferring his own interests to those of his principal.

Kamilewicz v Bank of Boston Corporation ${ }^{26}$ is frequently cited as evidence of this problem. The facts are stated by Judges Easterbrook and Posner in their dissent:

[The complaint was] that the Bank of Boston ... did not promptly post interest to real estate escrow accounts was filed in Alabama ... Settlement ensued, and the class members learned only what the notice told them. Few opted out or objected, because the maximum award to any class member was less than $\$ 9$. Any recovery, however small, seemed preferable to initiating a separate suit or even bearing the costs of protesting the settlement's terms. After the state judge approved the pact, the Bank carried out its part: it disbursed more than $\$ 8$ million to the class attorneys in legal fees and credited most accounts with paltry sums. Problem: the fees, equal to 5.32 percent of the balance in each account, were debited to the accounts. For many accounts the debit exceeded the credit. Dexter J. Kamilewicz, for example, received a credit of $\$ 2.19$ and a debit of $\$ 91.33$, for a loss of $\$ 89.14 .^{27}$

Similar 'sell-outs' can underlie settlements involving non-monetary compensation to class members. In these cases, coupons offering discounts on future purchases are distributed to class members, and the 'value' of the settlement is calculated on the total value of the distributed coupons, with the plaintiffs' attorneys remunerated accordingly. ${ }^{28}$ However, as the take-up rate of such coupons is roughly that of coupons distributed generally ${ }^{29}$ (or the coupons have significant restrictions on their redemption) the actual amount of compensation received by the class is trifling in comparison to the amount awarded to class counsel..$^{30}$ Comparable incentives occur when counsel is faced with diminishing marginal returns on the effort to seek a greater amount of compensation for the class. In such circumstances, counsel's motivation is to settle the action as effortlessly as possible, enabling counsel to focus energies on more profitable matters.

I make two observations regarding the agency issue. First, agency issues are pervasive in the lawyer-client relationship: they are not unique to class action matters. A lawyer paid on a piecework basis is motivated to produce the minimal acceptable quality result with the least amount of effort. Similarly, counsel paid by the hour has the incentive to maximise the hours spent on a file irrespective of the value that such effort will add to the client's cause. Further, those whose pay includes 'success fees' can exploit information asymmetries regarding the likelihood of 'successes' to ensure that bonus targets are met.

26. 100 F 3d 1348 (CA7 1996).

27. Ibid, at 1349 .

28. A pioneering study is JC Coffee Jr 'Class wars: the dilemma of the mass tort class action' (1995) 95 Colum L Rev 1343 at 1367-1368.

29. CR Leslie 'The need to study coupon settlements in class action litigation' (2004-2005) 18 Geo J Legal Ethics 1395 at 1396-1397.

30. In re Domestic Air Transportation Antitrust Litigation, 137 FRD 677 (ND Ga 1991) is perhaps the most infamous of the coupon settlement cases. See SB Hantler and RE Norton 'Coupon settlements: the emperor's clothes of class actions' (2004-2005) 18 Geo J Legal Ethics 1343 at 1344, and their summary, available at http://www.ftc.gov/bcp/workshops/classaction/ writ_materials/hantler.pdf 
Secondly, agency issues in class actions can be controlled by judicial approval of the conduct or settlement of the action. As a response to opportunistic behaviour manifested by class counsel, the US Class Action Fairness Act (CAFA) ${ }^{31}$ attempts to re-level the playing field away from class counsel. The CAFA requires, inter alia, that coupon settlements be valued by that portion of coupons actually redeemed, ${ }^{32}$ and that where fees are not related to the amount recovered by the class, the judicially approved fee be based on time worked..$^{33}$ Additionally, that Act has made it easier to remove class actions from state jurisdictions into the Federal Court system, ${ }^{34}$ thereby hindering the trial of these matters in state courts (particularly the so-called anti-business 'judicial hellholes' ${ }^{35}$ ).

Additionally, the Federal Rules of Civil Procedure (FRCP) require that judicial approval be given to counsel's remuneration. This approval has even extended to the means by which class counsel is selected, as the art auctions matter demonstrates. ${ }^{36}$ Enhanced judicial approval of class counsel's activities, including their relationship with the court and clients and their remuneration, can address some of the agency issues. Yet judicial monitoring is not a panacea to the class counsel-class agency problem. It introduces agency issues of a different sort: judges have their own incentives to determine the extent to which they will scrutinise settlements and the resulting remuneration of class counsel. ${ }^{37}$

\section{(c) Class formation and extortion from defendants}

The third point, that once a class has been formed, it is easy to use this to leverage a settlement from a defendant, is predicated on the truism that class certification is not just a threshold step in mass litigation. It is in many cases decisive. Given the non-recoverable expenditure of discovery costs or the risk of a damages award, settlement often ensues - settlement is frequently the rational option to a defendant. However, implicit in using claims of blackmail or extortion to describe the procedure by which such settlements can be obtained are two assumptions, both of which have

31. Codified 28 USC $\S \S 1332(d), 1453$ and 1711-1715.

32. Ibid $\S 1712$ (a).

33. Ibid § 1712(b)(1).

34. Ibid $\S \S 1553$ and 1711 .

35. American Tort Reform Association 'Bringing justice to judicial hellholes' (2002) quoted in Hantler and Norton, above n 30, summary at 2.

36. In re Auction Houses Antitrust Litigation 197 FRD 71 (SDNY 2000). That litigation arose out of the price-fixing of auction commissions by Sotheby's and Christie's. To determine the appointment of lead counsel, the court held an auction. After prequalification, the court conducted an auction based on one variable, X. The court described the auction (at 74): 'One hundred percent of any gross recovery up to and including $X$ was to go to the class. And twenty-five percent of any recovery in excess of $X$ would be paid to counsel, with the remainder going to the class. Each bid was to state the value of $X$ pursuant to which the bidder was prepared to serve as lead counsel.' On this cartel and some criticisms of the auction process, see O Ashenfelter and K Graddy 'Anatomy of the rise and fall of a pricefixing conspiracy: auctions at Sotheby's and Christie's' (2005) 1 J Comp L \& Econ 3.

37. SI Weisburst 'Judicial review of settlements and consent decrees: an economic analysis' (1999) 28 J Legal Stud 55; HA Sale 'Judges who settle' (2012) 89 Wash U L Rev 377. Further, the American system whereby state judges are elected aggravates agency issues: see Hantler and Norton's summary, above n 30, at 2-3. 
to be true for this argument to have significant force. These assumptions are: (1) that class formation is a sufficiently easy exercise, so that any aggrieved group can form a class and then sue; and (2) that the exposure to significant damages serves as a club to coerce an unjustified settlement. The first assumption is inaccurate, and demonstrably false in antitrust matters; the second reduces to the problem of statutory and punitive damages discussed previously.

Federal class actions are governed by FRCP r 23. This rule is in addition to those rules that govern the requirements for pleadings generally, which only require 'a short and plain statement of the claim showing that the pleader is entitled to relief' ${ }^{38}$ Subsequent case-law requires that this statement be something other than a 'formalistic recitation of the elements of a cause of action'. ${ }^{39}$

As Judge Easterbrook notes: 'One pleads a "claim for relief" by briefly describing the events. At this stage the plaintiff receives the benefit of imagination, so long as the hypotheses are consistent with the complaint. ${ }^{40}$ As applied to a $\S 1$ Sherman Act claim, the Supreme Court held:

... that stating such a claim requires a complaint with enough factual matter (taken as true) to suggest that an agreement was made. Asking for plausible grounds to infer an agreement does not impose a probability requirement at the pleading stage; it simply calls for enough fact to raise a reasonable expectation that discovery will reveal evidence of illegal agreement. ${ }^{41}$

Given that the discovery process in the USA can be a costly procedure, this threshold serves to provide an initial degree of protection to defendants who, given US litigation cost rules, will not be able to recover the costs for discovery should they ultimately prevail.

Further, FRCP r 23 requires proof of additional elements by prospective plaintiffs. Rule 23(a) sets out the prerequisites for class certification, requiring numerosity of class members, commonality of legal or factual issues to all class members, that the claims of the representative parties (named plaintiffs) are typical to the claims or defences of the class, and that the representative parties will fairly and adequately protect the interests of the class. Once the prerequisites of r 23(a) are established, the class action can be maintained under $\mathrm{r} 23(\mathrm{~b})$, which provides three bases for class actions:

- where there would be a risk of inconsistent adjudications, or where the adjudication of one matter would impair the interests of other members of the class (r 23(b)(1));

- where injunctive or declaratory relief is appropriate (r 23(b)(2)); or

- where questions of law or fact common to the class predominate over questions that affect only individual members (r 23(b)(3)).

The standard set by $\mathrm{r} 23(\mathrm{a})$ is high. ${ }^{42}$ In Wal-Mart $v$ Dukes, the majority of the USSC stated:

38. FRCP r 8(a)(2).

39. Bell Atlantic v Twombly 550 US 544 at 555, 127 S Ct 1955 at 1965 (2007).

40. See Sanjuan and Maviglia v American Board of Psychiatry and Neurology Inc $40 \mathrm{~F} 3 \mathrm{~d}$ 247 at 251 (CA7 1994).

41. Bell Atlantic, above n 39 , at 1965.

42. See A Andreangeli 'Collective redress in EU competition law: an open question with many possible solutions' (2012) 35 World Comp 529 at 536-548. 
Rule 23 does not set forth a mere pleading standard. A party seeking class certification must affirmatively demonstrate his compliance with the Rule - that is, he must be prepared to prove that there are in fact sufficiently numerous parties, common questions of law or fact, etc.... Frequently that ... will entail some overlap with the merits of the plaintiff's underlying claim. That cannot be helped. ${ }^{43}$

The minority did not disagree with this threshold; their disagreement was whether it had been met in the case. ${ }^{44}$

The consequences of these principles are visible in the 2013 decision of Comcast $v$ Berhand. ${ }^{45}$ That case involved alleged anti-competitive activity in the Philadelphia area cable television market. The plaintiffs alleged four theories of harm, and proposed certification of a class that included those who has been harmed by any of the four theories. In certifying the class containing all subsets of parties proposed by the plaintiffs, the District Court accepted only one of the theories of harm. ${ }^{46}$ The court further held that damages could be calculated on a class-wide basis. ${ }^{47}$ The certification was upheld by a majority of the Court of Appeals, ${ }^{48}$ which held that 'attacks on the merits of the methodology that have no place in the class certification inquiry'. ${ }^{49}$

The majority of the Supreme Court disagreed with this approach. It held that the test for predominance - in other words, that the same questions of law or fact apply to the class as a whole - was not met. The Court held:

The same analytical principles govern Rule 23(b). If anything, Rule 23(b)(3)'s predominance criterion is even more demanding than Rule 23(a)... .

By refusing to entertain arguments against respondents' damages model that bore on the arguments would also be pertinent to the merits determination, the Court of Appeals ran afoul of our precedents requiring precisely that inquiry. ... Without presenting another methodology, respondents cannot show Rule 23(b)(3) predominance: Questions of individual damage calculations will inevitably overwhelm questions common to the class. ${ }^{50}$

A class cannot be assembled in a willy-nilly fashion. To be certified, there must be sufficient evidence that the class is determined by common issues of law or fact, and that resolution of these issues will generally end the dispute. ${ }^{51}$ As similar issues surrounding extent and cause of damages befall certification of classes containing

43. 564 US -, $131 \mathrm{~S}$ Ct 2551 (2011), internal references omitted.

44. Ibid at $2565-2566$.

45. 569 US - , - S Ct - (2013) (decided 27 March 2013).

46. Behrend v Comcast 264 FRD 150 at 165 (ED Pa 2010).

47. Majority Slip opinion, above $\mathrm{n} 45$, at 4 .

48. Behrend v Comcast $655 \mathrm{~F} 3 \mathrm{~d} 182$ (CA3 2011).

49. Ibid, at 207.

50. Comcast, above $\mathrm{n} 45$, at majority's slip opinion at 6-7, see also Blades v Monsanto 400 F 3d 562 at 575 (CA8 2005): '. . . if [plaintiffs] propose to use such a method to prove injury, they must show that it could work to prove classwide injury with common evidence'.

51. For instance, as the majority in Comcast, ibid at slip opinion 7, held, predominance will not be found where 'Questions of individual damage calculations will inevitably overwhelm questions common to the class.' 
both direct and indirect purchasers, ${ }^{52}$ courts generally refuse to certify classes containing both types of members.

Commonality 'is satisfied when each class member's claim arises from the same course of events, and each class member makes similar legal arguments to prove the defendant's liability'. ${ }^{53}$ Similar criteria govern r 23(a)'s requirement of typicality:

Rule 23(a)'s typicality requirement is established where, as here, the claims of the representative Plaintiffs arise from the same course of conduct that gives rise to the claims of the other Class members, where the claims are based on the same legal theory, and where the class members have allegedly been injured by the same course of conduct as that which allegedly injured the proposed representatives. ${ }^{54}$

Given that direct purchasers are likely to be injured in the same manner by the same conspiracy and have suffered the same sorts of damages (though in varying amounts), their claims are more amenable to resolution as a class.

Indirect purchasers are a different matter. Depending on that purchaser's level in the distribution chain, the pass-through rate (ie the amount of overcharge due to the cartelised price paid by the purchaser) may be different. This rate can differ from vendor to vendor. As one District court concluded, 'tracing the alleged overcharges from manufacturers, to wholesalers, to retailers, to consumers presents individualized issues which would dominate this litigation and preclude certification under rule 23(b)(3)'.55

Such treatment of classes of indirect purchasers is not uncommon. ${ }^{56}$ Given that they can suffer harms in numerous ways, as members of a class, indirect purchasers will have sufficiently differing interests to make a vigorous and common pursuit of all of their interests impossible. Further, as the theories of harm and quantification of damages between direct and indirect purchasers are possibly opposed to each other, there would probably be insufficient common interest between the two groups to permit both types of claimants to be members of the same class. ${ }^{57}$ Additionally, counsel's duty of undivided loyalty to her client should preclude representation of classes with varying interests, not just from an ethical standpoint, but would prevent counsel from receiving fees in such a situation. ${ }^{58}$

52. The decision in Illinois Brick $v$ Illinois 431 US 720, 97 S Ct 2061 (1977) holds that under federal law indirect purchasers cannot make claims for damages. However, under the state law of jurisdictions that have passed 'Illinois Brick-repealer' statutes, such damages are available and can be pursued in federal courts.

53. In re the Drexel Burnham Lambert Group, Inc $960 \mathrm{~F} 2 \mathrm{~d} 285$ at 291 (CA2 1992).

54. In re NASDAQ Market-Makers Antitrust Litigation 169 FRD 493 at 511 (SDNY 1996), citing In re Drexel Burnham ibid, at 291.

55. In re Brand Name Prescription Drugs Antitrust Litigation 1994 WL 663590 (ND Ill) *7.

56. See inter alia Allied Orthopedic Appliances, Inc v Tyco Healthcare Group LP, 247 FRD 156 (CD Cal, 21 December 2007); Heerwagen v Clear Channel Communications, 435 F 3d 219 (CA2 2006); Blades v Monsanto Co, 400 F 3d 562 (CA8 2005); Valley Drug Co v Geneva Pharmaceuticals Inc, 350 F 3d 1181 (CA11 2003); In re Microsoft Corporation Antitrust Litigation, 218 FRD 449 (D Md 2003).

57. A similar concern has been raised in Canada: Pro-Sys Consultants Ltd et al v Microsoft Corporation et al, Sun-Rype Products Ltd et al v Archer Daniels Midland Company et al and Samsung Electronics Co Ltd et autres v Option Consommateurs et autres (Supreme Court of Canada Docket Numbers 34282, 342823 and 34617; jointly heard 17 October 2012).

58. See Rodriguez, v Disner 688 F 3d 645 (CA9 2012); and Image Technical Service, Inc v Eastman Kodak Co 136 F 3d 1354 (CA9 1997). 
To the degree that the foregoing demonstrates the extent to which courts will engage in scrutinising class composition and the merits of a proposed case, this calls into question the accuracy of those claims that class certification is in effect a quick, pro forma matter. A check on the homogeneity of interests of the proposed class and merits of the case insures screening on the proposed case. The nature of the American, 'user-pays' costs system provides an incentive for potential defendants to vigorously challenge the class certification; as once the class is certified, discovery (an expensive process) is the next stage in the litigation process. Given that the defendant's expenses that occurred during the discovery process are likely to be both significant and non-recoverable, such a defendant will have a considerable incentive to oppose the certification of the class, and have the matter disposed of at an early stage.

The second element of that criticism, namely that once formed, a class action lawsuit is a vehicle to extort unjustified settlements from defendants, implicitly assumes that defendants are overcompensated. Although these concerns are exacerbated within the context of the American triple-damages regime, ${ }^{59}$ these concerns will nevertheless reduce to earlier concerns regarding punitive and statutory damages discussed above.

Fears of 'damages extortion' are nothing more than a restatement of fears regarding the potentially overcompensatory effect of punitive damages. To the extent to which punitive or multiplied damages are either capped by a particular jurisdiction (such as the punitive damages regime in England and Wales ${ }^{60}$ ) or are seen as a means of 'topping up' what would otherwise be an inadequate award to fully compensate victims, ${ }^{61}$ shouts of 'extortion' should become muted. I also note that punitive damages can be awarded in competition matters in the UK. ${ }^{62}$

Further, although the US has a highly developed class action regime that is very effective in vindicating the rights of those harmed by anti-competitive activity, it is not the only potential model. Canada could serve as a model. All provinces permit such actions, with Quebec (the sole civil law province) first introducing such proceedings in $1978 .{ }^{63}$ Class certification is tightly controlled in all provinces (the issue of whether the class can contain both direct and indirect purchasers is still before the Canadian courts ${ }^{64}$ ). Punitive damages are not available in competition matters. ${ }^{65}$ Cost recovery is based on a modified English rule, whereby the unsuccessful litigant is responsible for their opponent's costs, albeit at a rate set by a tariff. This rate, while in effect only partially compensating the winning party for its costs, can result in significant cost awards. ${ }^{66}$ The American class action system is thus not the only such system, and to

59. Section 4(a) of the Clayton Antitrust Act of 1914 (codified as 15 USC $\S 15$ (a)) provides for, inter alia, threefold recovery of antitrust damages. The justification for this was to provide an incentive for private enforcement of the antitrust laws.

60. See eg Rookes v Barnard [1964] AC 1129 (HL); Broome v Cassell \& Co Ltd [1972] AC 127 (HL); Kuddus v Chief Constable of Leicestershire Constabulary [2001] UKHL 29.

61. See RH Lande 'Are antitrust "treble" damages really single damages?' (1993) 54 Ohio St L J 115.

62. 2 Travel Group plc (In Liquidation) v Cardiff City Transport Services Limited [2012] CAT 19.

63. Quebec Code of Civil Procedure, RSQ Ch C-25, ss 999-1051.

64. See the cases cited, above $\mathrm{n} 57$.

65. Wong $v$ Sony of Canada Ltd [2001] OJ No 1707, 9 CPC (5th) 122 (Ont SC); 321665 Alberta Ltd v Mobil Oil Canada Ltd [2013] ABCA 221 (Alta CA).

66. In Consumers' Association of Canada v Coca-Cola Bottling Company et al [2006] BCSC 1233 , the costs were estimated to be about $\$ 400,000$. 
use it as such simply ignores other reasonable systems that have had the benefit of many years of testing.

The lesson of this section has been to explode some myths surrounding opt-out class actions generally and particularly those notorious stories told about the US class action system. While there may be a small element of truth in some of what is said regarding the American system, these shortcomings have been exaggerated. With this in mind, I turn to the European context in an effort to determine what this American lesson - cleansed of the folklore elements - can teach us.

\section{THE EUROPEAN CONTEXT OF PRIVATE COMPETITION ENFORCEMENT AND COLLECTIVE ACTIONS}

\section{(a) Private enforcement}

Although the European Treaties are silent regarding the private enforcement of Arts 101 and 102, since the ECJ decisions in Courage and Crehan ${ }^{67}$ and Manfreidi, ${ }^{68}$ there has been no dispute that private damages are available for breaches of EU competition law.

The difficulty, however, is with the means by which damages can be obtained. In Manfredi, the ECJ indicated that this was a matter for national law, which controls the measurement of damages and the procedure by which damage claims are to be pursued. In addition to this nationalised nature of civil damages is the interaction of civil regimes with national public enforcement, as the aftermath of Pfleiderer ${ }^{69}$ instructs us. The consequence of this is that as these national laws are not harmonised, there is a patchwork of local regimes. In addition to the national law governing matters such as the measurement of competition damages (including potentially standing for indirect purchasers), such a patchwork also affects the ability of groups of harmed individuals to collectively pursue claims. This latter concern is of more general consequence, given its implication for redress in consumer and financial matters.

In competition matters, the Commission has rightly recognised that such a mosaic in determining the level of damage recovery leads to differing levels of protection throughout Europe ${ }^{70}$ and thus a certain degree of harmonisation is desirable to effective protection of European rights throughout the EU. The most recent attempt at

67. Case C-453/99 Courage Ltd v Bernard Crehan and Bernard Crehan v Courage Ltd and Others [2001] ECR I-6297, paras 25-27.

68. Cases C-295/04 to C-298/04, Vincenzo Manfredi and Others $v$ Lloyd Adriatico Assicurazioni SpA and Others [2006] ECR I-6641, para 62.

69. C-360/09, Pfliederer v Bundeskartellamt, NYR (Opinion of A-G Mazák, 16 December 2010; Judgment, 14 June 2011); see also T-437/08, CDC Hydrogene Peroxide v Commission, NYR (15 December 2011); T-344/08, T-344/08, En BW Energie Baden-Württemberg AG $v$ Commission, NYR (22 May 2012); C-536/11, Bundeswettbewerbsbehörde v Donau Chemie and Others, NYR (Opinion of Advocate General Jääskinen, 7 February 2013; Judgment, 6 June 2013); Pfliederer v Bundeskartellamt 51 Gs 53/09 AG Bonn (18 January 2012); National Grid Electricity Transmission PLC v ABB Ltd et al [2012] EWHC 869 (Ch) (4 April 2012).

70. Green Paper Damages Actions for Breach of the EC Antitrust Rules (presented by the Commission) \{SEC(2005) 1732\} Brussels, 19 December 2005 COM(2005) 672 final; White Paper on Damages Actions for Breach of the EC Antitrust Rules (2 April 2008) \{COM(2008) 165 final $\}$ \{SEC (2008) 405\} \{SEC (2008) 406\}. 
harmonisation, a Commission-inspired draft proposal for a Directive to harmonise private competition actions, ${ }^{71}$ attempts to establish common rules regarding disclosure of leniency materials and to develop standards to facilitate private redress in competition matters. As early as the 2005 Green Paper on actions in antitrust matters, ${ }^{72}$ the Commission identified six main obstacles to private redress, one of which was 'the lack of effective collective redress mechanisms, especially for consumers and SMEs' ${ }^{73}$ However, the proposed Directive, while addressing matters that would facilitate the ability of private individuals to bring claims (such as the probative value of national competition agencies' decisions in follow-on actions), failed to address collective actions.

Rather, on the same day on which the Proposed Directive was published, the Commission announced a general (ie not competition-specific) Recommendation on collective redress. ${ }^{74}$ While the Recommendation suggests that Member States adopt collective redress regimes, it also recommends that these regimes be based on an opt-in model, with the ensuing litigation not financed by contingency fees. ${ }^{75}$ The spectre of the American bogeyman played a prominent role in the press release that announced the publication of the Recommendation. It heralded:

'Member States have very different legal traditions in collective redress and the Commission wants to respect these. Our initiative aims to bring more coherence when EU law is at stake', said Vice-President Viviane Reding, the EU's Justice Commissioner. 'This Recommendation is a balanced approach to improve access to justice for citizens while avoiding a US-style system of class actions and the risk of frivolous claims and abusive litigation. ${ }^{, 76}$

It is unfortunate that this straw man was used, and possibly as a result of its use, an opt-in model was chosen as the Commission's preferred means. An opt-in model will permit the consolidation of small claims, making the aggregated action economical to pursue if a sufficient number sign up. However, opt-in actions will not overcome the problem of rational apathy. Claimants must nevertheless have sufficient motivation and/or incentive to join the class. A more compelling argument, however, is the argument based on respect for varying legal traditions. In the remainder of the paper,

71. Proposal for a Directive of the European Parliament and of the Council on certain rules governing actions for damages under national law for infringements of the competition law provisions of the Member States and of the European Union (11 June 2013) COM(2013) 404 final.

72. See the Green Paper, above n 70, passim.

73. Proposal for Directive, above n 71, p 4.

74. Commission Recommendation of $\mathrm{XXX}$ on common principles for injunctive and compensatory collective redress mechanisms in the Member States concerning violations of rights granted under Union Law, Strasbourg XXX, C(2013) 3539/3 (11 June 2013) (available at http://ec.europa.eu/justice/civil/files/c_2013_3539_en.pdf); and Communication from the Commission to the European Parliament, the Council, the European Economic and Social Committee and the Committee of the Regions 'Towards a European horizontal framework for collective redress', Brussels, XXX, COM(2013) 401/2 (available at http://ec.europa.eu/justice/ civil/files/com_2013_401_en.pdf).

75. European Commission Press Release 'Commission recommends Member States to have collective redress mechanisms in place to ensure effective access to justice' IP/13/524 (11 June 2013) (available at http://europa.eu/rapid/press-release_IP-13-524_en.htm).

76. Ibid. 
I examine this argument, along with the reception of collective actions generally in Europe and the UK.

\section{(b) Legal tradition, legal rules and party control of litigation}

The most significant barrier to opt-out collective actions lies in a deeply ingrained tradition of party control of litigation found in a number of continental jurisdictions. ${ }^{77}$ Although in the Anglo-American legal tradition it is a general principle that litigation can be pursued in the interests of 'individual named parties only', ${ }^{78}$ opt-out class actions are viewed as an exception and can be enabled through changes in either legislation or rules of procedure. However, this assumes the lack of a deeper legal (perhaps constitutional) or institutional aversion (possibly with cultural antecedents) to such collective litigation.

Such aversion can take the form of not just procedural rules, but also constitutional provisions that limit the ability of such procedural rules to be 'rewritten'. This view is particularly prevalent in Germany, where important principles of party control have their foundation in the German Constitution. Articles 2 and 103(1) of the German Constitution are taken to guarantee party autonomy and control over litigation. As commentators note, these provisions guarantee the litigant 'an opportunity to address the court in support of its own claims and in opposition to the assertions and proof of the opponent' ${ }^{79}$ The immediate consequence of this is that no one can be bound by the results of litigation, unless the litigant was before the court or agreed to be bound by the court's decision. As opt-out litigation is predicated on the principle that the results are binding on all, unless they opt out, such forms of collective litigation are precluded by these constitutional restrictions.

Similar restrictions, reflecting underlying legal attitudes, are found in the French Constitution. ${ }^{80}$ However, this is not to say that such jurisdictions are without a means of collective redress. Such means exist: opt-in regimes, actions pursued by consumer groups and assignments of rights to damages are among the alternatives. ${ }^{81}$ With the exception of a few jurisdictions, ${ }^{82}$ true collective actions are pursued by means of either opt-in regimes or by representative organisations (eg consumers' groups). However, in the presence of transaction costs, rational apathy and the agency and funding issues associated with representative actions ${ }^{83}$ one can expect fewer participants in such actions, with the result that less compensation flows to those harmed. ${ }^{84}$

77. This point is also made by Delatre, above $\mathrm{n} 8$, at $51-53$.

78. Califano v Yamasaki 442 US 682 at 701, 99 S Ct 2545 at 2557 (1979).

79. PL Murray and R Stürner German Civil Justice (Durham, NC: Carolina Academic Press, 2004) p 188.

80. In France, the case-law of the European Court of Justice directly binds judges, and Art 6-1 of the ECHR is taken to preclude opt-out collective action: see Dec. Cons. Const. No 89-257 DC, 25 July 1989.

81. On this point, see the country surveys in AA Foer and JW Cuneo (eds) The International Handbook on Private Enforcement of Competition Law (Cheltenham: Edward Elgar, 2010).

82. See R Mulheron 'The case for an opt-out class action for European Member States: a legal and empirical analysis' (2009) 15 Colum J Eur L 409 at 421-425.

83. See eg Van Den Bergh, above n 2, at 29-32.

84. And not to mention a decreased element of deterrence, to the extent that private actions supplement the deterrent effect of public enforcement. 


\section{(c) The Dutch collective redress regime}

As an alternative to opt-out class actions of the American sort (and without its perceived excesses), the 2005 Dutch Act on Collective Settlement of Mass Actions $\left(\mathrm{WCAM}^{85}\right)$ is often heralded as providing an appropriate pattern for collective redress legislation. ${ }^{86}$ This act built upon earlier (1994) changes to the Dutch Civil Code (Art 3:305a-c CC) that permitted collective actions to be brought by a foundation or an association on behalf of others. These entities must be non-profit organisations, thereby excluding profit-making groups (eg law firms) from participating in (if not driving) the litigation. The Civil Code does not permit claims for damages under this provision (but foundations and associations can obtain declaratory relief on liability, and injunctions and specific performance). However, as this process does not allow for damage claims, individuals must make a subsequent application to receive such compensation.

The WCAM allows for a collective settlement made by an agreement between a foundation or an association representing parties to whom damage was caused and those responsible for compensating the victims (eg the undertaking or their insurers). ${ }^{87}$ Upon reaching the agreement, the parties can apply to the Amsterdam Court of Appeal for approval of the agreement. The criteria for judicial scrutiny include matters such as reasonability of the settlement and whether the foundation is a fair representative of the affected class. ${ }^{88}$ If the agreement is approved, a claimant has the ability to opt out of the settlement.

The difficulty solved by the WCAM is that of finality: in the event of a mass claim, once liability is established, the defendant will wish to settle all possible claims, thereby removing all contingent liability arising from the incident from its balance sheet. The WCAM arose from litigation regarding the liability of pharmaceutical companies for the consequences of the use of DES (diethylstilbestrol) during pregnancy. Desire to settle the litigation with finality resulted in amendments to the Dutch Civil Code and Code of Civil Procedure to provide a means that would grant the industry (and other defendants similarly situated in the future) the finality it needed.

Among the ostensive advantages of the Dutch system is that unlike opt-in matters, once the matter is certified by the Amsterdam Court, all parties are known, and the matter can be settled with those who are members of the class, and the identities (and perhaps the claims) of those who have opted out can be subject to later settlement or trial. Further, the fact that such litigation is driven by non-profit associations is seen as an advantage, as the removal of the profit motive is touted as removing some of the agency issues associated with self-interested, profit-making entities conducting litigation. ${ }^{89}$

85. Wet Collectieve Afhandeling Massachade; Netherlands Civil Code 7:907-910 and Code of Civil Procedure Art 1013.

86. See eg Department for Business, Innovation and Skills Private Actions in Competition Law: A Consultation on Option for Reform - Government Response (Document BIS/13/501) (London: BIS, January 2013) paras 5.23 and 6.20-6.26.

87. Netherlands Civil Code Art 7:907(1).

88. Ibid, Art 7:907(3).

89. However, in spite of the non-profit nature driving such litigation, other agency issues will arise: see Van Den Bergh, above n 2, at 22-24' 31-32. 


\section{COLLECTIVE REDRESS: EUROPEAN PROPOSALS AND THE UK'S RESPONSE}

\section{(a) The European proposals}

A number of EU proposals have discussed the need to address the circumstances in which private actions for competition injuries can be brought within the Union. These proposals have been put forth not just by the Commission's DG-Competition, but also by the DG-Sanco (Health and Consumers) and the European Parliament. The varying mandates of these bodies that produced documents on collective actions indicate the more general nature for the need to develop some form of collective redress to deal with the small-harm problem. These sorts of injuries are more than merely a competition problem.

Notwithstanding the general nature of the problem, the bulk of the Union's work has been focused on competition harms. The 2004 Green Paper (produced by DG-Comp) launched a series of consultations regarding the conditions under which private competition damages could be obtained in Member States, and surveys of obstacles that preclude the effective enforcement of private rights of action. ${ }^{90}$ In addition to this work, the European Parliament has produced works of its own on antitrust. ${ }^{91}$ The work of both of these bodies has focused on identifying barriers to effective redress resulting from issues such as standing (particularly for indirect purchasers), quantification of damages and the passing-on defence, and proposing suggestions for reform. This is done in some detail.

In contrast, perhaps implicitly recognising the diversity in European legal traditions, there is relatively little detail in the discussions regarding collective actions. The 2012 Report of the Parliament's Directorate-General for Internal Policies is agnostic as between opt-in and opt-out collective actions, ${ }^{92}$ recognising that while the former preserve the liberty of those who may be affected by the claim, opt-out actions achieve finality and address the problem of rational apathy, though potentially at the risk of encouraging unmeritorious claims.

This agnosticism is not shared by other reports. The Staff Report to the Commission's 2008 White Paper (again produced by DG-Comp) exhibited a strong preference for opt-in actions..$^{93}$ The White Paper itself reflected this attitude, to the extent that possibilities for opt-out actions were not considered. Indeed, Delatare notes:

90. In addition to the White Paper and Green Paper (n 70), see also Ashurst (A Firm) Study on the Conditions of Claims for Damages in Case of Infringement of EC Competition Rules: Comparative Report (Brussels: Ashurst, 2004); Commission Staff Working Paper Accompanying the White Paper on Damages Actions for Breach of the EC Antitrust Rules $\{\mathrm{COM}(2008)$ 165 final $\}$ \{SEC (2008) 405\} \{SEC (2008) 406\} Brussels, 2 April 2008, SEC(2008) 404; and Commission Staff Working Paper Annex to the Green Paper Damages Actions for Breach of the EC Antitrust Rules \{COM(2005) 672 final\} Brussels, 19 December 2005 SEC(2005) 1732.

91. European Parliament Directorate-General for Internal Affairs Collective Redress in Antitrust (Brussels: EU Publications, June 2012), available at http://www.europarl.europa .eu/committees/en/studiesdownload.html?languageDocument=EN\&file=74351; European Parliament Committee on Legal Affairs Report on 'Towards a Coherent European Approach to Collective Redress' (2011/2089(INI)) A7-0012/2012 (12 January 2012), available at http:// www.europarl.europa.eu/sides/getDoc.do?type=REPORT\&reference=A7-20120012\&language $=\mathrm{EN}$.

92. Collective Redress, ibid, pp 65-67.

93. White Paper, above n 70, p. 21. 
It is unclear why these options [for opt-out class actions] were not put forward by the White Paper. ... More surprising still is the fact that the options appear not to have been considered at all by the Commission. As argued above, considering the European experience with collective redress mechanisms, and opt-out actions in particular, the reality is that the debate on the opt-out class action never truly took place. ${ }^{94}$

The European Parliament's Committee on Legal Affairs' 2012 Report on collective redress generally is even more adamant. In its motion for a parliamentary resolution, it states:

[The European Parliament] [n]otes the efforts made by the US Supreme Court to limit frivolous litigation and abuse of the US class action system, and stresses that Europe must refrain from introducing a US style class action system or any system which does not respect European legal traditions; . . .

Against this background, it is little wonder that the recent Draft Proposal for a Directive on private enforcement ${ }^{96}$ avoids the issue entirely.

In it, the Commission leaves such discussion to a Recommendation, ${ }^{97}$ which suggests a preference for an opt-in regime, though permitting Member States the option of an alternative in the interests of the administration of justice. ${ }^{98}$ An accompanying Communication explains the Commission's rejection of opt-out thus:

The 'opt-out' system gives rise to more fundamental questions as to the freedom of potential claimants to decide whether they want to litigate. The right to an effective remedy cannot be interpreted in a way that prevents people from making (informed) decisions on whether they wish to claim damages or not. In addition, an 'opt-out' system may not be consistent with the central aim of collective redress, which is to obtain compensation for harm suffered, since such persons are not identified, and so the award will not be distributed to them.

The Commission therefore takes the view in the Commission Recommendation that under the European horizontal framework on collective redress the claimant party should be formed on the basis of the 'opt-in' method and that any exception to this principle, by law or by court order, should be duly justified by reasons of sound administration of justice. ${ }^{99}$

Opt-in is thus the Commission-recommended default, as it allows individual determination over whether or not to litigate. This preference is in spite of the fact that opt-in may never give rise to the global finality that opt-out systems provide: a point that the Commission fails to consider.

94. Delatre, above $\mathrm{n} 8$, at 57 .

95. Report, above n 91, para 2, reference to Wal-Mart $v$ Dukes omitted.

96. Above $n 71$.

97. Above $\mathrm{n} 74$.

98. Ibid, para 21: 'The claimant party should be formed on the basis of express consent of the natural or legal persons claiming to have been harmed ("opt-in" principle). Any exception to this principle, by law or by court order, should be duly justified by reasons of sound administration of justice.'

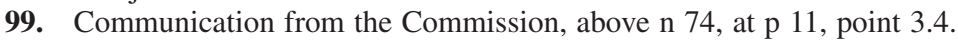




\section{(b) The UK's response}

It has been a long-standing principle of English law that private individuals can seek damages for breaches of the competition provisions of the European Treaties. ${ }^{100}$ In addition, s 47B of the Competition Act 1998 provides that claims can be brought on behalf of consumers, by specified bodies on an opt-in basis. ${ }^{101}$ However, any discussion of s 47B must also keep in mind the underwhelming result of its only use to date in Replica Football Kits.

In addition, in Emerald Supplies Ltd and ANR v British Airways, ${ }^{102}$ the claimants attempted to use the provisions of $r 19.6$ of the Civil Procedure Rules (CPR) to extend the class of claimants by acting as representatives of those who suffered damages as a result of (in the words of the claim) the fact that they were "purchasers of air freight services the prices for which were ... inflated'. ${ }^{103}$ The High Court denied this application on the basis that (as pled) the identification of class members (those who had been affected by inflated prices) was dependent on the outcome of the action (proof of inflated prices). Thus the proposed class was not identifiable at the time the claim was issued, as required by the CPR. ${ }^{104}$ Further, and more fundamental to the focus of the present paper, the proposed class would include both direct and indirect purchasers. As r 19.6(1) requires similarity of interests, the court held that certification under this rule would be improper, given the divergent interests of the two types of purchasers. ${ }^{105}$ The Court of Appeal upheld this ruling, agreeing with the reasoning. ${ }^{106}$ It is against the above background that any discussion of reforms of the English regime regarding collective redress in competition actions should be considered.

The OFT's 2007 discussion paper on private actions ${ }^{107}$ was published the month following the filing of the notice for claim for damages in Replica Football Kits. This paper was a proactive attempt at a response to the Commission's then forthcoming White Paper. ${ }^{108}$ The discussion paper, without the benefit of the experience that Replica Football Kits would provide, remained wedded to the advantages of the representative action regime. While it raised the possibility of opt-out actions, ${ }^{109}$ it explicitly raised (without addressing) the concern that such actions - by removing an individual's control over his or her wish 'to be bound by the outcome of the action' 110 - may be incompatible with the Human Rights Act 1998 (HRA). ${ }^{111}$ To enhance the

100. Garden Cottage Foods v Milk Marketing Board [1984] AC 130; An Bord Bainne Co-operative Ltd v Milk Marketing Board [1984] 2 CMLR 584; Bourgeoin SA v Minister of Agriculture Fisheries and Food [1985] 1 CMLR 528.

101. Competition Act 1998, s 47B(3).

102. Sub nom Emerald Supplies Limited and Southern Glass House Produce Limited v British Airways plc [2010] EWCA Civ 1284, [2011] 2 WLR 203.

103. Emerald Supplies [2009] EWHC $741(\mathrm{Ch})$, para 2.

104. Ibid, paras 33-35.

105. Ibid, paras 36-37.

106. Emerald Supplies (CA), above n 102, paras 62-65.

107. Office of Fair Trading Private Actions in Competition Law: Effective Redress for Consumers and Business: Discussion Paper (OFT916) (London: OFT, April 2007).

108. Ibid, para 1.1 .

109. Ibid, para 4.23 .

110. Ibid, para 4.24 .

111. While further analysis of the compatibility of opt-out collective actions and the HRA is well beyond the scope of this paper, it is worth noting the following: if the suggestion is true and such actions are incompatible with the HRA, then this provides further evidence of legal/

(C) 2014 The Authors. Legal Studies published by John Wiley \& Sons Ltd on behalf of the Society of Legal Scholars 
regime, the paper suggested extending the availability of representative actions to businesses, ${ }^{112}$ and expanding the set of representative bodies to permit courts to grant standing to organisations on an ad hoc basis. ${ }^{113}$

In addition to the work of the Commission to improve and potentially harmonise private enforcement of competition law, the failures of the Replica Football Kit action, and the decisions in Emerald Supplies and in English Welsh \& Scottish Railway Ltdv Enron Coal Services Ltd ${ }^{114}$ (the latter restricting the ability of the Competition Appeal Tribunal (CAT) to hear follow-on claims), were influential in subsequent British discussion regarding such reform. The Department for Business, Innovation and Skills Consultation of April 2012 uses these three failures as examples of why the present system may be viewed as not working. ${ }^{115}$

That Consultation introduced the government's preferred option, an opt-out regime to include both business and consumers, with tight controls over group certification, a preliminary merits test, adequacy of representation and - given the desire that the traditional English rule regarding costs be retained - assurance that the representative have sufficient resources to cover the defendant's costs if the action proved unsuccessful. ${ }^{116}$ This regime would include expanded jurisdiction of the CAT to hear such claims. ${ }^{117}$ It did recognise some advantages of the American system; it was often used as a foil, particularly in discussions of damages, costs and the use of unmeritorious cases to extract a settlement from defendants. ${ }^{118}$

The OFT's response to this aspect of the consultation was one of strong support, with the caveat that appropriate safeguards be in place to avoid 'abusive litigation'. ${ }^{119}$ The recommended safeguards included the court's vetting of proposed representatives and 'strong case management as the case proceeds'. ${ }^{120}$ This of course, is nothing more than a veiled exhortation to avoid at least the perceived excesses of the American system.

The government's response, published in January 2013, is based on the Dutch WCAM. The response describes the government's decision in the following terms:

Under this system a representative of those who believe they have suffered a loss as a result of an infringement of antitrust rules and a potential defendant would jointly apply to the CAT to approve on an opt-out basis a mutually agreed settlement agreement. It would also in principle be possible for a defendant to settle

traditional barriers to the adoption of such actions. On the other hand, if this suggestion is false and these actions are compatible with the HRA, then the suggestion is perhaps yet another bogeyman story.

112. Ibid, para 4.8 .

113. Ibid, paras 4.14-4.15.

114. [2009] EWCA Civ 647.

115. Department for Business, Innovation and Skills Private Actions in Competition Law: A Consultation on Options for Reform (Document BIS/12/742) (London: BIS, April 2012) para 3.14.

116. Ibid, paras 3.21, 5.1-5.53 and Annex A.

117. Ibid, para 3.21 .

118. Ibid, paras A.5-A.12.

119. Office of Fair Trading Private Actions in Competition Law: A Consultation on Options for Reform: The OFT's Response to the Government's Consultation (OFT1434resp) (London: OFT, July 2012) para 1.12.

120. Ibid. 
with multiple representatives, each representing different categories of claimants (e.g. direct and indirect purchasers) simultaneously. ${ }^{121}$

A number of safeguards would be put into place to ensure fairness to the claimants, particularly approval of the settlement and counsel's remuneration, and the ability of claimants to opt out of the settlement. ${ }^{122}$ In arguing for the need for these safeguards, the spectre of American excesses was invoked, both by the government and a number of the respondents. ${ }^{123}$

The suggestion for an opt-out system, for UK-domiciled claimants, is only a limited step forward to a more effective regime of public redress in competition matters. The Dutch WCAM on which the initiative will be patterned is a means for collective settlements. Patterning the UK model on this act may facilitate the resolution of group claims: it will do nothing to aid in the initiation of such claims; nor will it effectively resolve matters if a defendant is unwilling to enter into a settlement. Without there being a risk of a more costly judgment imposed upon the defendant in the event that the action does not settle, a defendant has no incentive to enter into settlement discussions, never mind concluding a settlement. To be effective a collective action regime requires a means to assemble such an action, and bring it before a court under threat of a judgment.

The dread of an American-style culture of meritless class actions, which are settled out of concern that a jury may award a significant sum to a non-deserving, illcomposed class of claimants, has influenced European thought regarding the suitability of collective action. Time after time, such rhetoric arises. But, as this section also shows, the value of individual control over litigation, and the need for consent to have one's legal rights altered, are vital principles of the legal traditions of the eastern side of the Atlantic. This principle is entrenched not just as a matter of international convention, but has a constitutional status in several influential jurisdictions.

\section{CONCLUSION: RATIONAL APATHY AND THE EUROPEAN NON-SOLUTION}

Although it is a principle of European law that individuals are to have an effective remedy for harms done by violations of their European rights, in competition law matters at least, the efficacy of this remedy is measured by national law. Where the harm done is small, and the costs of attempting to rectify it exceed the harm, rational apathy is the appropriate response. The alternatives are either to create a continent of Posnerian irrationality and fanaticism or to allow the aggregation of such small claims into larger actions that are worthwhile to pursue.

Unless these small claims can be vindicated, those harmed by anti-competitive activity will be uncompensated. Such activity will also be under-deterred, as it is

121. Department for Business, Innovation and Skills Private Actions in Competition Law: A Consultation on Options for Reform - Government Response (Document BIS/13/501) (London: BIS, January 2013) paras 6.20-6.21.

122. Ibid, paras 5.72 and $6.22-6.25$.

123. Ibid, para 5.33: 'The great majority of respondents strongly agreed with Government that, if an opt-out system were to be introduced, there would be a need for strong safeguards to protect against vexatious claims or frivolous litigation. In the words of the law firm Herbert Smith, the system "must provide adequate safeguards to prevent unmeritorious claims being brought, avoiding the excesses of the US class action system" ' (footnote omitted). 
unrealistic to suggest that public enforcement will be able to completely eliminate it. To create conditions in which those claiming compensation are required to act in an economically irrationally manner is socially wasteful: the court resources needed to deal with tens (if not hundreds) of thousands of identical, small claims certainly far exceed the resources needed to resolve one, larger, mass claim.

The clear solution is some means of aggregating such claims. The rhetoric surrounding opt-out aggregation has been to taint it as inviting the excesses of the American system. Yet when considered carefully, each of the features of that system viewed as an American excess need not be seen as a fatal flaw to an opt-out class action system. Procedural rules regarding class certification are not as weak or flexible as the opponents of the American system would make them out to be. Wal-Mart and Comcast show the tight reign put on class membership. Further, there is no need to a priori automatically transplant FRCP r 23 as the means of defining and certifying classes: alternative models can be designed.

Similarly, the fear of disproportionate damages is a concern not about class actions, but in regard to the role of punitive damages in a system of civil liability and vindication of rights. For historical reasons, the US Congress permitted treble damages for breaches of competition law. This was justified as an incentive for private action to supplement public enforcement. Again, punitive (or multiplied) damages and class actions are independent matters; there is no reason to suppose that adopting the former necessarily brings with it the latter. Although punitive damages can be awarded in the UK for competition matters, ${ }^{124}$ public policy considerations in other European jurisdictions ${ }^{125}$ preclude these sorts of damages. Compare with Canada, which has a moderately developed class action regime in competition matters, but where punitive damages are not available.

Agency issues can be a problem in class actions. Indeed, the American experience provides some evidence of this. But again, this is not a problem that is exclusive to class actions. As agency issues can arise in any relationship where responsibility is delegated, they are often manifested in behaviour in the lawyer-client relationship. The solutions to control over the problems that can arise from this divergence of interests can be found in vetting (probably by courts) of counsel's remuneration and by addressing the funding issue more generally. Indeed, in any discussion of effective, collective actions (of whatever sort), their funding is the elephant in the room. ${ }^{126}$

An opt-in regime is a poor substitute. It does not effectively address the problem of rational apathy: victims must still undergo the hassle of signing up to the action. Signing up may consist in filling out and posting off a coupon, completing a form (perhaps on the Internet) or some other means of contacting a representative. While the appropriate thresholds may be lower for signing up to an action as opposed to litigating one, there is an opportunity cost to time, and opting into an action may well exceed this cost. Further, an opt-in regime will not result in the global resolution of claims. An opt-in action, by definition, will bind only those who sign on. Those who do not sign on may still have a valid claim against the defendant, and can be free to form a new action to vindicate their interests. With these considerations in mind, a potential defendant may not feel as strongly motivated to resolve these claims as it

124. See 2 Travel and text accompanying note 62 , above.

125. For example, in France the legal maxim 'tout le dommage, mais rien que le dommage' ('all the damage, but nothing more than the damage') applies to compensation.

126. On this point and its relevance to collective actions in competition matters, see C Veljanovski 'Third-party litigation funding in Europe' (2012) 8 J L, Econ \& Pol'y 405. 
might were a global solution available. The Dutch solution, opt-out collective settlements, does not fully resolve the problem: it leaves unaddressed the prior problem of bringing the defendant to the table and incentivising it to negotiate a resolution.

When children are frequently threatened with the bogeyman, they come to believe in its existence. They won't sleep due to fear, and a dutiful parent must then take a flashlight and shine it around the bedroom closet to show the child that there is no bogeyman in there. I hope this paper has had an analogous effect on fears of American class actions. But notwithstanding the removal of these fears, there may be other, more fundamental barriers to the import of opt-out class actions into Europe: these latter reasons are based on legal traditions with probably cultural roots. But having this origin, these barriers may not be overcome with the same ease as the fear of the American bogeyman that echoes in discussions of class actions. 